\section{Lo sublime en Ran de Akira Kurosawa}

Alfonso Cisneros
E n el libro Elogio de la sombra de E Yunichiro Tanizaki descubrimos cómo el autor va introduciendo de manera evocativa la singular belleza de los objetos artísticos, el vivo encanto de elementos cotidianos, gracias al tamiz del resplandor que destella dentro de la oscuridad. Lo oculto accede a penetrar hacia el misterio que se desnuda en reposo: reflejos de luz que rozan con debilidad y delicadeza los lugares más secretos de nuestra interioridad.

El alumbramiento e intensidad que despierta en los sentidos, asoma imperceptiblemente hacia el asombro. Lo velado nos conduce bajo un halo silencioso al encuentro de ese encanto sutil; eco de contemplación y culto propio del goce estético.

La naturaleza es parte de un ritual tradicional propio del Japón; una vocación de internarnos hacia el corazón del cosmos, entre luces y aromas plenos de fragancias y colores, como la floración del cerezo, que despierta en primavera y cuyo esplendor tan solo dura pocos días, reflejando así la fugacidad de la vida, la belleza de lo efímero.

El célebre haiku de Katzu puede sugerirnos en tan solo tres versos ese estado de naturalidad:

Viento agitado

mudándose de rama

la flor del cerezo

Pero lo que pretende esta breve reflexión parte de un claro motivo ligado 
a lo bello y lo sublime: alusiones hacia la vacuidad y el silencio. Un nuevo pero distinto acercamiento que no nos inhibe de rescatar otras formas del comportamiento estético japonés: el aspecto de lo sublime relacionado con lo trágico en una escena cinematográfica de la película Ran del realizador Akira Kurosawa.

Kurosawa recrea en la secuencia de la toma del castillo imágenes delirantes y sangrientas de la batalla en las que no advertimos sonidos naturales, como el estruendo que producen las carretas de soldados, los caballos al galope, las luchas cuerpo a cuerpo, sino el fascinante efecto de contraste y contrapunto entre música e imagen: los personajes parecen moverse con más lentitud y la escena alcanza mayor intensidad y un sutil patetismo gracias al Adagio con que Toru Takemitzu acompaña el motivo de la batalla en Ran y que su música, al no seguir la acción fielmente, ofrece un fascinante efecto de contraste, similar al que una voz solista puede provocar sobre un constante ostinato en el que solo imagen y música comparten este fragmento.

Particularmente estaríamos hablando, entonces, de un contrapunto analógico entre la puesta en escena y la acción de lo real. La diégesis (lo que la pantalla nos muestra) se mueve dentro de un significado paralelo entre lo que se ve y lo que se sugiere. Lo no diegético (en este caso música agregada a la escena y que dentro del contexto de lo representado no escuchan los personajes) genera una metáfora sintética que actúa en oposición a la propia imagen, matizando y agregando efectos ambivalentes.

Si las características del arte japonés van ligadas a la belleza, la meditación, el recogimiento y la quietud, en el fragmento de la película Ran (Caos) aparece la sangrienta lucha, que por más de seis minutos de duración, nos muestra imágenes patéticas, delirantes, de horror, muerte, suicidio acompañadas por el sugestivo tratamiento de la música.

Hablando sobre lo sublime, Longino reflexiona:

Sin pathos no se puede concebir lo sublime. O bien surge de una pasión que todo lo penetra, o bien es sugerido por múltiples emociones combinadas, que en su síntesis impresionan de un modo completamente distinto a como lo hubieran podido hacer cada uno por separado. Lo trágico, relacionado con lo espantoso, es una forma de esta sublimidad; pero también es la poesía amorosa de Safo, que es fuego y hielo, llanto y risa, sabiduría y locura, temblor y deseo, vida y muerte. La sublimidad de una descripción homérica de la tempestad es resultado de una unidad sintética de destellos impresionantes y espantosos. ${ }^{1}$

1 ESTRADA HERRERO, David. Estética. Barcelona: Editorial Herder S.A., 1988, p. 635. 
Kurosawa, en la escena del castillo, podría haber mostrado en las imágenes mayor crudeza y patetismo, eligiendo un score que refuerce la tragedia: efectos delirantes, atonales, continuos sonidos de percusión, acordes disonantes e intensos, apoyándose en sonidos naturales como gritos desesperados, zumbido de flechas, estallido de armas de fuego, voces y quejidos agonizantes dentro de un espacio desolador y desesperado. Pero el cine permite matizar y recrear gracias al contrato audiovisual nuevas manifestaciones por donde el horror se transforma en sublime.

De la interacción entre música e imagen se obtienen resultados completamente sorprendentes. Así, Michel Chion anota:

En la combinación audiovisual, una percepción influye en la otra y la transforma: no se 've' lo mismo cuando se oye; no se 'oye' lo mismo cuando se 've' (...). Una escena inmersa, pero coloreada de alegría o tristeza mediante la música, parecerá explicar por sí misma este sentimiento, sin necesidad aparente de la música. Inversamente, la propia música será coloreada de cierta manera por la escena a la que está asociada. Así imagen y música exacerban recíprocamente su expresión. ${ }^{2}$

En referencia al tema, Roberto Cueto hace la siguiente alusión:
La música intensifica así la singularidad o importancia de una escena determinada y evita la reiteración y la cacofonía al repetir lo que es obvio visualmente: cuando aparece es que esa escena posee un valor determinado y le añade una dimensión nueva, diferente a lo visto anteriormente (...). Por ejemplo, en la batalla del filme Ran (1985), de Akira Kurosawa, una música belicosa y marcial hubiera implicado una glorificación del combate y la batalla, pero el Adagio que escuchamos muestra el comentario del director, una triste visión de los horrores que pueden traer los excesos de ambición y poder. ${ }^{3}$

Debido al contraste entre música e imagen, la secuencia se apropia de un contrapunto poético. Las imágenes de horror se ven veladas por el tratamiento de un sutil patetismo.

Referencias que no encontramos en otros filmes como La pasión de Cristo de Mel Gibson. Allí, las representaciones son crudas, delirantes, sin que se produzca el efecto sugerido de lo sublime y mucho menos de aquello espantoso pero estético de que nos habla Longino. En La pasión de Cristo, las secuencias nos afectan hasta el delirio y la insatisfacción, aunque la propuesta sea otra.

En Ran, sangre, muerte, agonía develan un tratamiento estético: la música ilumina las imágenes sombrías, las envuelve de misterio y evocación hacia nuevas significaciones.

2 CHION, Michel. La audiovisión. Barcelona: Ediciones Paidos Ibérica S.A., 1998, p. 11.

3 CUETO, Roberto. Cien bandas sonoras en la historia del cine. Madrid: Nuer Ediciones, 1996, p. 22. 